\title{
Thermal Conductivity of Tetryl by Modulated Differential Scanning Calorimetry
}

\author{
R.K. Weese
}

This article was submitted to

$4^{\text {th }}$ International Symposium on the Heat Flow Calorimetry of Energetic Materials Leeds, United Kingdom

September 7-10, 2003

U.S. Department of Energy

July 28, 2003

\section{Lawrence}

Livermore

National

Laboratory

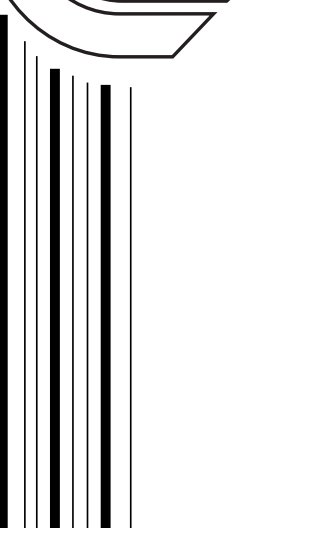




\section{DISCLAIMER}

This document was prepared as an account of work sponsored by an agency of the United States Government. Neither the United States Government nor the University of California nor any of their employees, makes any warranty, express or implied, or assumes any legal liability or responsibility for the accuracy, completeness, or usefulness of any information, apparatus, product, or process disclosed, or represents that its use would not infringe privately owned rights. Reference herein to any specific commercial product, process, or service by trade name, trademark, manufacturer, or otherwise, does not necessarily constitute or imply its endorsement, recommendation, or favoring by the United States Government or the University of California. The views and opinions of authors expressed herein do not necessarily state or reflect those of the United States Government or the University of California, and shall not be used for advertising or product endorsement purposes.

This is a preprint of a paper intended for publication in a journal or proceedings. Since changes may be made before publication, this preprint is made available with the understanding that it will not be cited or reproduced without the permission of the author.

This report has been reproduced directly from the best available copy.

Available electronically at http://www.doc.gov/bridge

Available for a processing fee to U.S. Department of Energy

And its contractors in paper from

U.S. Department of Energy

Office of Scientific and Technical Information

P.O. Box 62

Oak Ridge, TN 37831-0062

Telephone: (865) 576-8401

Facsimile: (865) 576-5728

E-mail: reports@adonis.osti.gov

Available for the sale to the public from

U.S. Department of Commerce

National Technical Information Service

5285 Port Royal Road

Springfield, VA 22161

Telephone: (800) 553-6847

Facsimile: (703) 605-6900

E-mail: orders@ntis.fedworld.gov

Online ordering: http://www.ntis.gov/ordering.htm

OR

Lawrence Livermore National Laboratory

Technical Information Department's Digital Library

http://www.llnl.gov/tid/Library.html 


\title{
Thermal Conductivity of Tetryl by Modulated Differential Scanning Calorimetry
}

\author{
Randall K. Weese \\ Energetic Materials Center, Lawrence Livermore National Laboratory, Livermore, \\ California, 94550, USA \\ E-mail: weese2@1lnl.gov \\ Phone: (925) 424-3165 \\ Fax: (925) 424-3281
}




\title{
Thermal Conductivity of Tetryl by \\ Modulated Differential Scanning Calorimetry
}

\author{
R. K. Weese \\ (Energetic Materials Center, Lawrence Livermore National Laboratory, Livermore, California 94550)
}

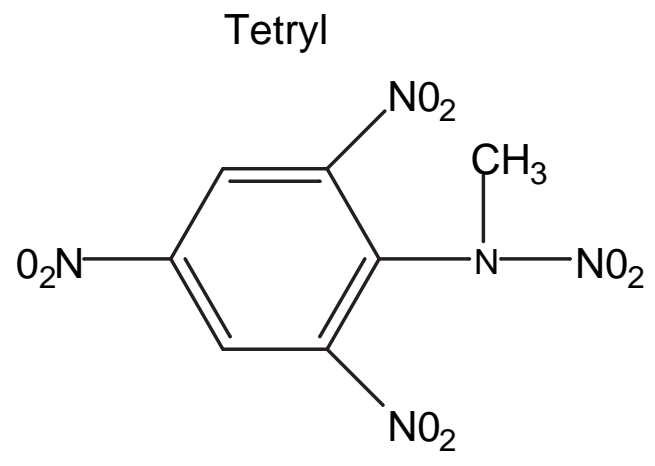

\begin{abstract}
We investigated the use of the Modulated Differential Scanning Calorimeter to measure thermal conductivity $(K)$ of the explosive, Tetryl, using two different methods, isothermal and nonthermal. A discussion of our methods and a comparison of our measured values to literature values of $\mathrm{K}$ for Tetryl, which deviated by as much as $50 \%$, will be presented.
\end{abstract}

(Key Words: thermal conductivity; apparent heat capacity; isothermal; non-isothermal; MDSC)

\section{Introduction}

Computational models to predict violent and non-violent reactions in high explosives are becoming important. Lawrence Livermore National Laboratory (LLNL) has developed 
computer codes and material models to simulate time temperature dependence of energetic materials to aid in the prediction for cook off events [1]. Evaluating a material and its properties are important for various reasons. The ease at which heat is transferred by a material can be of great importance and have a major impact on the material's use, stability and ultimately its safety. Materials such as high explosives generally do not conduct well and often are compared to insulator like materials, while metals and the like are considered conductors because of their efficiencies in conducting or transporting energy. Conductors [2] typically have thermal conductivities in the range of $10-400 \mathrm{~W}^{\circ} \mathrm{C}^{-1}$ $\mathrm{m}^{-1}$, while insulators have thermal conductivities in the range of 0.2 to $2 \mathrm{~W}^{\circ} \mathrm{C}^{-1} \mathrm{~m}^{-1}$. Textbook and literature values are useful references to experimenters but are often given as single values at ambient temperatures. Information such as this does not always suffice for experiments such as thermal cook-off where a dynamic temperature range is involved. Here we measure the energetic material, Tetryl, and observe the thermal property thermal conductivity, $K$.

Thermal modeling is becoming an accepted method of predicting the behavior of materials and often real experimental data is needed to feed these sophisticated models.

\section{Theory}

Modulated DSC (MDSC) is a well-known technique [3], which provides not only the same information that conventional DSC does, but also provides information not available from conventional DSC [4], such as the simultaneous measure and separation of the reversible and non-reversible heat components. Heat capacity is calculated in MDSC based on Discrete Fourier Transformation [5] where the 
difference in the measured amplitudes of the sample and heat flow modulation is compared to a reference sine wave of the same frequency [3]. The information acquired by MDSC often allows experimenters to increase their knowledge of material properties in a time efficient manner. In MDSC, the heating rate changes during the modulation cycle. During a specified modulated heating cycle the heating rate is at its fastest rate at the maximum, when the modulation is at the minimum the heating rate is at its slowest rate. This is analogous to conventional DSC where runs at two different heating rates are used to compare the difference in heat flow to a sample and calculate specific heat. Marcus and Blaine have stated [2] that de-convolution of the data collected by MDSC provides many advantages;

(1) separation of the total heat flow component into the components of reversible heat flow and non-reversible heat flow [2]

(2) direct measurement of the specific heat capacity [2]

(3) increased resolution and sensitivity of subtle and often overlapping transitions [6], [7]

Modulation (sinusoidal oscillation) of the heat rate is superimposed on the linear heating rate resulting in a combined heating profile seen in figure 1. The isothermal heating profile used for calibrations and samples analyzed by the isothermal method is shown in figure 2.

The heat flux model can express heat capacity where equation 1 is the basic equation to derive $C_{p}[3]$. 


$$
\mathrm{C}_{\mathrm{p}}=\mathrm{K}_{\mathrm{cp}}\left(\mathrm{Q}_{\mathrm{amp}} / \mathrm{T}_{\mathrm{amp}}\right)(\text { Modulation Period } / 2 \pi)
$$

$$
\begin{aligned}
& \text { Where: } \quad \mathrm{C}_{\mathrm{p}}=\text { heat capacity }\left(\mathrm{J} / \mathrm{g} /{ }^{\circ} \mathrm{C}\right) \\
& \mathrm{K}_{\mathrm{cp}}=\text { heat capacity calibration constant } \\
& \mathrm{Q}_{\mathrm{amp}}=\text { heat flow amplitude }(\mathrm{W} / \mathrm{g}) \\
& \mathrm{T}_{\mathrm{amp}}=\text { temperature amplitude }\left({ }^{\circ} \mathrm{C}\right)
\end{aligned}
$$

The enthalpy of a substance increases as its temperature is raised. The relationship between the increase in enthalpy and the increase in temperature depends on the conditions that are maintained, such as constant volume or constant pressure [8]. In this experiment heat capacity measured at constant pressure was used to relate the change in enthalpy to the change in temperature. The increase in enthalpy can be expressed as the heat supplied to a sample at constant pressure as,

$$
\mathrm{q}_{\mathrm{p}}=\mathrm{C}_{\mathrm{p}} \Delta \mathrm{T}
$$

Equation 2 shows us how to measure the heat capacity [8] of a sample, as it is quantitatively measured while heat is supplied under conditions of constant pressure and the temperature change is being monitored. Figure 3 is the measured apparent heat capacity, $C$.

The measure of thermal conductivity can be carried out using several different instrumental techniques. The associated heat flow of a material permits the measurement of transitions that occur with respect to time and temperature. Measurement of kinetic and thermodynamic processes such as glass transition, melting point, degree of cure, percent crystallinity, and rate of decomposition are just some of the more common MDSC measurements [2]. Equation 3 calculates the observed thermal conductivity of the sample $[9]$. 


$$
K_{o}=\left(\frac{8 L C^{2}}{C_{p} M d^{2} P}\right)
$$

$$
\begin{aligned}
& \text { Where: } \quad K_{o}=\text { observed thermal conductivity }\left(\mathrm{W}^{\circ} \mathrm{C}^{-1} \mathrm{~m}^{-1}\right) \\
& \mathrm{L}=\text { sample length }(\mathrm{mm}) \\
& \mathrm{C}=\text { apparent heat capacity }\left(\mathrm{mJ} /{ }^{\circ} \mathrm{C}\right) \\
& \mathrm{C}_{\mathrm{p}}=\text { specific heat capacity }\left(\mathrm{J} / \mathrm{g}^{\circ} \mathrm{C}\right) \\
& \mathrm{M}=\text { specimen mass }(\mathrm{mg}) \\
& \mathrm{d}=\text { specimen diameter }(\mathrm{mm}) \\
& \mathrm{P}=\text { period of measurement (seconds) }
\end{aligned}
$$

It is the intention of these analysis parameters to analyze Tetryl over a dynamic temperature range under isothermal and non-isothermal conditions. The analysis parameters in this work were established to gather both non-isothermal and isothermal thermal conductivity in a time effective manner.

\section{Experimental}

Physical heat transport measurements outlined by TA Instruments [3] was used in this study. Modulated differential scanning calorimetry (MDSC) [10] measures the difference in the heat flow between a sample and an inert reference measured as a function of time and temperature (see equation 1). Both the sample and reference are subjected to a controlled environment of time, temperature, pressure, and atmosphere. The instrument design used for making MDSC measurements in this work is the heat flux design. TA Instruments, New Castle, Delaware, Model 2920 [11]. 
In this design, a metallic alloy disk, made of constantan, is the primary means of heat transfer to and from the sample and reference [12]. As heat is transferred through the disc, area thermocouples formed by the junction of the constantan disc and chromel wafers, which cover the underside of the platforms, measure the temperature difference and hence the differential heat flow between the sample and reference. Chromel and alumel wires attach to the chromel wafers and form thermocouples, which directly measures the voltage difference between the sample and reference and converts to temperature. The dynamic sample chamber (furnace) composition is a silver alloy used to insure good temperature uniformity. Purge gas (nitrogen, helium, oxygen, etc.) is admitted to the sample chamber through an orifice in the heating block before entering the sample chamber. The result is a uniform, stable thermal environment, which assures better baseline flatness and sensitivity (signal-to-noise) [3].

Temperature and heat flow calibrations were carried out as outlined [3] using indium, lead, tin, and zinc metals along with sapphire standard reference materials. Thermal conductivity calibration was performed using two polystyrene specimens. The thin sample weighed approximately $14.90 \mathrm{mg}$ and was approximately $0.5 \mathrm{~mm}$ thick with a diameter of approximately $6.38 \mathrm{~mm}$. The thick sample weighed approximately $117.81 \mathrm{mg}$ with a length of approximately $3.53 \mathrm{~mm}$ and a diameter of approximately $6.38 \mathrm{~mm}$. (The two sample lengths are used based on the premise that the thin sample obtained equilibrium and the thick sample did not reach equilibrium.) The specific heat capacity $C_{p}$ apparent heat capacity $C$, and the thermal conductivities $K_{o}$ were obtained using standard MDSC procedures [3] and ASTM E 1952-98 [13]. 
Two Tetryl sample masses were needed: one of approximately 15-20 mg and the other of approximately $250 \mathrm{mg}$. All samples were pressed using a cold steel die of approximately $6.4 \mathrm{~mm}$ in diameter. A maximum press pressure of 30,000 pounds per square inch, psi, was used for all samples.

Isothermal and non-isothermal analysis conditions were defined prior to all calibrations and analyses to optimize measurements and to minimize thermal lag [10]. For sapphire, the temperature range used was approximately $-40^{\circ} \mathrm{C}$ to $220^{\circ} \mathrm{C}$, for polystyrene and Tetryl the temperature range used was approximately $-40^{\circ} \mathrm{C}$ to $80^{\circ} \mathrm{C}$.

Isothermal measurements were carried out over a temperature range of approximately $-23^{\circ} \mathrm{C}$ to $77^{\circ} \mathrm{C}$. Analysis data was collected by cooling the sample, with a TA refrigerated cooling unit, $\mathrm{RCA}$, to a sub ambient temperature of $-23^{\circ} \mathrm{C}$. Once the temperature was achieved the computer program held the temperature isothermally 20 minutes. After each 20-minute isotherm the temperature was increased at $3^{\circ} \mathrm{C}$ per minute, stepping in intervals of $10^{\circ} \mathrm{C}$ at a time until a maximum temperature of $77^{\circ} \mathrm{C}$ was reached. A modulated temperature program with modulation amplitude of $\pm 0.5^{\circ} \mathrm{C}$ over a 100 second period was maintained throughout (see figure 2).

Non-isothermal measurements were carried over a temperature range of approximately $-40^{\circ} \mathrm{C}$ to $80^{\circ} \mathrm{C}$ using a linear heating ramp rate of $3^{\circ} \mathrm{C}$ per minute, with a modulation amplitude of $\pm 0.5^{\circ} \mathrm{C}$ over a 100 second period (see figure 1 ).

In this study, the thermal conductivity of Tetryl was evaluated at $-3^{\circ} \mathrm{C}, 17^{\circ} \mathrm{C}$ and $47^{\circ} \mathrm{C}$ under isothermal and non-isothermal conditions. These temperatures were chosen to 
represent the dynamic temperature range of this experiment. (See appendix A for nonisothermal and isothermal sample masses and dimensions.)

\section{Results}

Tables 1 and 2 compare non-isothermal and isothermal polystyrene values obtained by MDSC with literature values. The \% variation values show the accuracy and the precision of these thermal conductivity measurements. The results shown in table 1 have a bias of approximately $0.05-0.06\left(\mathrm{~W}^{\circ} \mathrm{C}^{-1} \mathrm{~m}^{-1}\right)$ between the observed values and the literature values while the precision about these measurements shows an average variation of approximately $34.7 \%$ and a standard deviation of the $\%$ variation of approximately $1.2 \%$ by comparison.

Table 1 compares the non-isothermal thermal conductivity of polystyrene without corrections. The precision is distinguishably better for the non-isothermal method when compared to the isothermal method. On the other hand, the accuracy is distinguishably worse than the isothermal method (see tables 1 and 2).

Table 2 compares the isothermal thermal conductivity of polystyrene without corrections. The accuracy is distinguishably better for the isothermal method, and the precision is distinguishably worse than the non-isothermal method (see tables 1 and 2).

The samples dimensional configuration is thought to be a source of thermal energy loss via the surface area not in intimate contact with the thermocouple. The $\%$ variation seen in table 1 between the thermal conductivities measured and literature values may be a result of poor sample thermal interface (i.e. silicon oil) and the effects of poor heat transfer of the 
carrier gas. Marcus [2] and associates believe that for very low conductivities such as polystyrene and materials in this category, the thermal conductivity of the nitrogen purge gas surrounding the sample influences thermal transport.

In theory, the effect of the purge gas can be reduced or even eliminated by encapsulating the sample specimen in such a way that thermal transport takes place only at the thermocouple interface, thus reducing discrepancies due to sample shape and purge gas thermal transport. The use other inert gases such as argon, krypton, or xenon $(0.018,0.010$, and $0.0058 \mathrm{~W}^{\circ} \mathrm{C}^{-1} \mathrm{~m}^{-1}$ ) [14] that have low thermal conductivities may improve thermal conductivity measurements.

In an effort to insure intimate contact between sample and thermocouple, silicon oil is applied to each thermocouple and sample at their contact points. It is assumed that this silicon oil will transport heat and is used in the measure of apparent heat $\mathrm{C}\left(\mathrm{mJ} /{ }^{\circ} \mathrm{C}\right)$. It is assumed that because calibration requires this application that the effects of the silicon oil are trivial proves to be false. The solubility of a material (not shown in this work) with the silicon oil may have a direct effect on the observed analysis [15]. Tetryl samples were observed to look dark and wetted at the thermocouple sample interface, where the silicone oil was applied, this was not observed in the polystyrene samples. For this experiment the assumption that the silicon oil was constant for the calibrations and samples is at best a poor assumption.

In principle the loss of heat through the sides and the top of all samples are accounted for with the calibration constant D which is used for thermal conductivity [2]. Equation 6 
calculates the D-cell calibration constant for the sample to correct for heat loss due to sample configuration [9].

$$
\mathrm{D}=\left(K_{o} * K_{r}\right)^{0.5}-K_{r}
$$

Where: $\quad K_{o}=$ uncorrected thermal conductivity

$K_{r}=$ reference thermal conductivity

The $\mathrm{D}$ cell constant is typically within the range of $0.02-0.05 \mathrm{~W}^{\circ} \mathrm{C}^{-1} \mathrm{~m}^{-1}$. The $\mathrm{D}$ cell constant value may then be substituted into equation 5 to obtain the unknown material thermal conductivity. Equation 5 was used to calculate the corrected value for thermal conductivity [9].

$$
K=\left[K_{o}-2 D+\left(K_{o}^{2}-4 D K_{o}\right)^{0.5}\right] / 2
$$

Tables 1 and 2 show the uncorrected thermal conductivities and the accuracy and precision of this measurement. The accuracy of the isothermal method proves better by a significant factor, while the precision of the non-isothermal method was significantly better than the isothermal method, when compared within themselves.

Tetryl was analyzed by both isothermal and non-isothermal methods. Listed in table 3 are the observed non-isothermal and isothermal corrected values of Tetryl compared to literature values.

Literature values for thermal conductivities of Tetryl span a range of $0.084-0.286\left(\mathrm{~W}^{\circ} \mathrm{C}^{-1}\right.$ $\mathrm{m}^{-1}$ ). This variation may be the result of many factors such as density, purity, and analysis 
method to name a few. Table 4 is a comparison of the experimentally observed thermal conductivities of Tetryl and a range of literature thermal conductivity values $[14,16,17,18,19]$. Measured thermal conductivities by both non-isothermal and isothermal methods values fall approximately in the middle of the cited literature values. Thus the comparison of non-isothermal versus isothermal values described here appears to provide accuracy and precision at least equivalent to other reported works that measure insulator type materials without the expense for a specialized apparatus.

The purpose of this work was to lay a path for more works of this type. In the comparison of non-isothermal analysis versus isothermal analysis the isothermal analysis reported higher thermal conductivities. Heat is usually lost in experiments and measured values are typically lower than the true value, therefore the higher the measured value the better the measurement method.

(See appendix B and C for the observed corresponding non-isothermal and isothermal specific heat capacity and apparent heat capacity measurements for this experiment.)

\section{Acknowledgements}

This work performed under the auspices of the U.S. Department of Energy by the Lawrence Livermore National Laboratory under contract number W-7405-Eng-48.

I would like to thank Dr. Jerry Forbes and Dr. Jon Maienschein of Lawrence Livermore National Laboratory, Livermore, CA, for their support in this work. 


\section{References}

1. M.A. McClelland, T.D. Tran, B.J. Cunningham, R.K. Weese, and J.L. Maienschein, UCRL-JC-144009 “Cook-off response PBXN-109: Materials Characterization and ALE3D Predictions", Lawrence Livermore National Laboratory, Livermore, CA, May 29,2001, JANNAF, Salt Lake City, UT, July 11-13, 2001

2. S.M. Marcus, R.L. Blaine, Thermochimica Acta 243 (1994) 231-239

3. Modulated DSC Compendium, Basic Theory and Experimental Conditions, TA Applications Brief, TA Instruments, New Castle, Delaware

4. M. Reading, B.K. Hahn, B.S. Crowe, Method and Apparatus for Modulated Differential Analysis, US Patent 5224775 (1993)

5. W.H. Press, B.P. Flannetry, S.A. Teukolsky and W.T. Vetterling; Numerical Recipes, the Art of Scientific Computing, 1986, Cambridge University Press, Cambridge, pp. 386-390

6. TA Instruments, Publication MDSC 2, TA Applications Brief, New Castle, Delaware,

7. TA Instruments, Publication TA 074, TA Applications Brief ,New Castle, Delaware,

8. P. Atkins, Physical Chemistry, $6^{\text {th }}$ Edition, W.H. Freeman and Company, New York, 1998

9. Procedure to Measure Thermal Conductivity by MDSC, TA Instruments, New Castle, Delaware, PN 915067.001 Rev. A, July 1995

10. V.A. Bershtein, V.M. Egorov, Differential Scanning Calorimetry of Polymers, Ellis Horwood Limited, 1994

11. TA Instruments, TA Applications Brief, Publication MDSC 1, New Castle, Delaware 
12. TA Instruments Short Course Outline, TA Applications Brief, C.Y. Ho, et.al. NBS, New Castle, Delaware

13. Annual Book of ASTM Standards, Standard Test Method for Thermal Conductivity and Thermal Diffusivity by Modulated Temperature Differential Scanning Calorimetry, Vol. 14.02, designation: E-1952-98

14. R.H. Perry, D.W. Green, and J.O. Maloney, Perry's Chemical Engineering Science, $6^{\text {th }}$ edition, McGraw-Hill, New York (1984) p. 3-254

15. R.K. Weese and J. Maienschein, Physical Characterization of HMX, RDX, PETN and TATB by Modulated Differential Scanning Calorimetry, Lawrence Livermore National Laboratory, Livermore, California 94550 (Work-In-Progress)

16. R.E. Bolz and G.L. Tuve, CRC Handbook of Tables for Applied Engineering Science, $2^{\text {nd }}$ edition, CRC Press, Inc., Boca Raton, Florida, 1976, p. 50

17. B.E. Drimmer, Navy Bank of Explosives Data, Technical Report, Vol. III, June 1983, Defense Technical Information Center, Defense Logistics Agency, Cameron Station, Alexandria, Virginia

18. A.F. Belyaev, N. Matyushko, C.R. Acad. Sci. USSR; Vol. 30, p. 629 (1941)

19. B.M. Dobratz, “LLNL Explosives Handbook-Propeties of Chemical Explosives and Explosive Simulants"; UCRL-52997, Lawrence Livermore National Laboratory, Livermore, CA; March 16, 1982; with Errata of Jan 28, 1985 
Table 1

Comparison of non-isothermal thermal conductivities of polystyrene $\left(\mathrm{W}^{\circ} \mathrm{C}^{-1} \mathrm{~m}^{-1}\right)$ without correction

\begin{tabular}{cccc}
\hline temperature, ${ }^{\circ} \mathrm{C}$ & $\mathrm{K}_{o}, \mathrm{~W}^{\circ} \mathrm{C}^{-1} \mathrm{~m}^{-1}$ & literature value, $\mathrm{W}^{\circ} \mathrm{C}^{-1} \mathrm{~m}^{-1}$ & $\%$ variation \\
\hline-3 & 0.2012 & 0.1499 & 34.2 \\
17 & 0.2039 & 0.1523 & 33.9 \\
47 & 0.2121 & 0.1558 & 36.1 \\
\hline
\end{tabular}

Table 2

Comparison of isothermal thermal conductivities of polystyrene $\left(\mathrm{W}^{\circ} \mathrm{C}^{-1} \mathrm{~m}^{-1}\right)$ without correction

\begin{tabular}{cccc}
\hline temperature, ${ }^{\circ} \mathrm{C}$ & $\mathrm{K}_{\mathrm{o}}, \mathrm{W}^{\circ} \mathrm{C}^{-1} \mathrm{~m}^{-1}$ & literature value, $\mathrm{W}^{\circ} \mathrm{C}^{-1} \mathrm{~m}^{-1}$ & $\%$ variation \\
\hline-3 & 0.1696 & 0.1499 & 13.1 \\
17 & 0.1646 & 0.1523 & 8.1 \\
47 & 0.1593 & 0.1558 & 2.2 \\
\hline
\end{tabular}


Table 3

Comparison of corrected Tetryl thermal conductivities $\left(\mathrm{W}^{\circ} \mathrm{C}^{-1} \mathrm{~m}^{-1}\right)$

\begin{tabular}{cccc}
\hline temperature, ${ }^{\circ} \mathrm{C}$ & $K, \mathrm{~W}^{\circ} \mathrm{C}^{-1} \mathrm{~m}^{-1}$, non-isothermal & $K, \mathrm{~W}^{\circ} \mathrm{C}^{-1} \mathrm{~m}^{-1}$, isothermal & \% variation \\
\hline-3 & 0.171 & 0.186 & 8.2 \\
17 & 0.165 & 0.186 & 13.8 \\
47 & 0.154 & 0.189 & 18.6 \\
\hline
\end{tabular}

Table 4

Comparison of corrected Tetryl thermal conductivities $\left(\mathrm{W}^{\circ} \mathrm{C}^{-1} \mathrm{~m}^{-1}\right)$ at $17^{\circ} \mathrm{C}$ and reported literature values $\left(\mathrm{W}^{\circ} \mathrm{C}^{-1} \mathrm{~m}^{-1}\right)$

\begin{tabular}{ccc}
\hline material & experimental & literature $[14,16,17,18,19]$ \\
\hline Tetryl (non-isothermal) & 0.165 & $0.084-0.286$ \\
Tetryl (isothermal) & 0.186 & $0.084-0.286$ \\
\hline
\end{tabular}




\section{Caption of figures}

Figure 1: MDSC non-isothermal heating profile of sapphire:

Abscissa represents temperature, ${ }^{\circ} \mathrm{C}$

Left ordinate represents modulated temperature, ${ }^{\circ} \mathrm{C}$

Right ordinate represents the derivative of the modulated temperature ${ }^{\circ} \mathrm{C} /{ }^{\circ} \mathrm{C}$

Figure 2: MDSC isothermal heating profile of polystyrene:

Abscissa represents time in minutes

Left ordinate represents modulated temperature, ${ }^{\circ} \mathrm{C}$

Right ordinate represents the derivative of the modulated temperature

${ }^{\circ} \mathrm{C} /$ minutes

Figure 3: MDSC isothermal heating profile of polystyrene:

Abscissa represents time in minutes

Left ordinate represents heat flow, $\mathrm{W} / \mathrm{g}$

Right ordinate (blue) represents the modulated temperature ${ }^{\circ} \mathrm{C}$

Right ordinate (maroon) represents the apparent heat capacity, $\mathrm{mJ} /{ }^{\circ} \mathrm{C}$ 
Figure 1

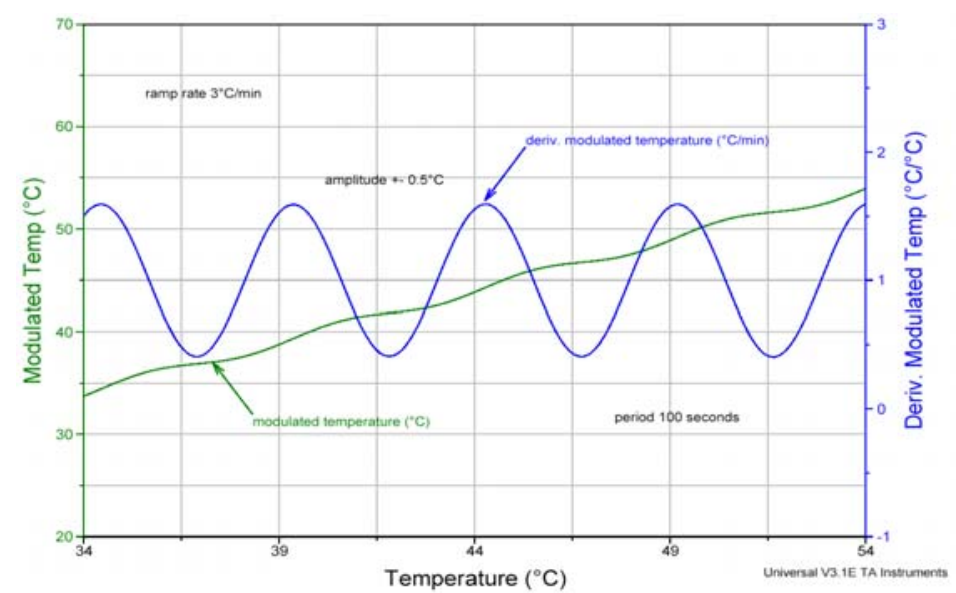

Figure 2

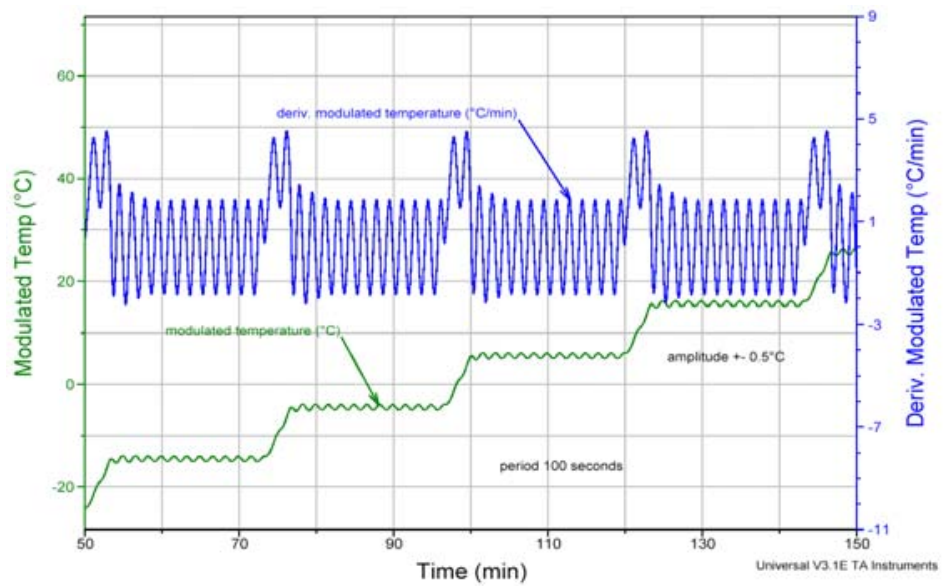

Figure 3

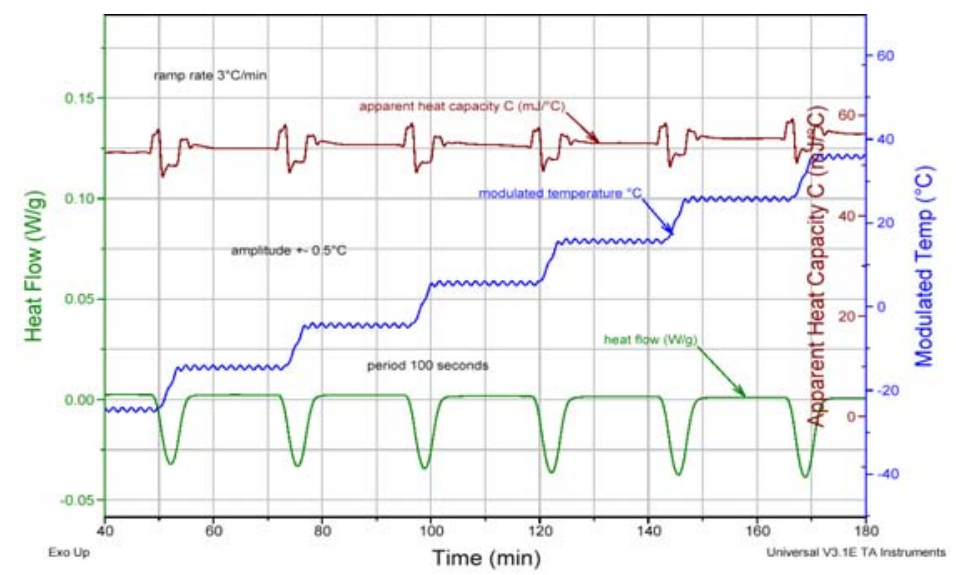




\section{Appendices}

\section{Appendix A}

Masses, lengths and diameters of non-isothermal and isothermal Tetryl samples.

\begin{tabular}{lccc}
\hline sample & mass, $\mathrm{mg}$ & length, $\mathrm{mm}$ & diameter, $\mathrm{mm}$ \\
\hline thin (non-isothermal) & 19.8 & 0.4 & 0.4 \\
thick (non-isothermal) & 249.3 & 4.6 & 6.3 \\
thin (isothermal) & 19.4 & 0.4 & 0.4 \\
thick (isothermal) & 248.9 & 4.6 & 6.3 \\
\hline
\end{tabular}

\section{Appendix B}

Observed non-isothermal and isothermal specific heat capacity of Tetryl, $\mathrm{J} / \mathrm{g}^{\circ} \mathrm{C}$.

\begin{tabular}{ccc}
\hline temperature, ${ }^{\circ} \mathrm{C}$ & $\mathrm{Cp}$ (non-isothermal) $\mathrm{J} / \mathrm{g}^{\circ} \mathrm{C}$ & $\mathrm{Cp}$ (isothermal) $\mathrm{J} / \mathrm{g}^{\circ} \mathrm{C}$ \\
\hline-3 & 0.812 & 0.80 \\
17 & 0.863 & 0.844 \\
47 & 0.939 & 0.910 \\
\hline
\end{tabular}

\section{Appendix C}

Observed non-isothermal and isothermal apparent heat capacity of Tetryl, $\mathrm{mJ} /{ }^{\circ} \mathrm{C}$.

\begin{tabular}{ccc}
\hline temperature, ${ }^{\circ} \mathrm{C}$ & $\mathrm{C}$ (non-isothermal) $\mathrm{mJ} /{ }^{\circ} \mathrm{C}$ & $\mathrm{C}$ (isothermal) $\mathrm{mJ} /{ }^{\circ} \mathrm{C}$ \\
\hline-3 & 69.40 & 66.32 \\
17 & 70.76 & 66.98 \\
47 & 72.79 & 68.53 \\
\hline
\end{tabular}

